\title{
USE OF FLASH FLOOD POTENTIAL INDEX (FFPI) METHOD FOR ASSESSING THE RISK OF ROADS TO THE OCCURRENCE OF TORRENTIAL FLOODS - PART OF THE DANUBE BASIN AND PEK RIVER BASIN
}

\author{
Mladen Marković ${ }^{1}$, Sara Lukić ${ }^{2}$, Aleksandar Baumgerte ${ }^{3}$ \\ ${ }_{1,2,3}$ Department of Ecological Engineering for Soil and Water Resources Protection, University of Belgrade \\ Faculty of Forestry, Belgrade 11000, Serbia \\ ${ }^{1}$ Public Enterprise "Roads of Serbia", Belgrade 11000, Serbia
}

Received 25 June 2021; accepted 5 August 2021

\begin{abstract}
Torrential floods are the one of the most frequent natural hazards in the Republic of Serbia, which cause severe damage to a road network, change a traffic regime and endanger a traffic safety. The occurrence, extent and duration of the torrential floods, can be predicted based on experience, statistics and modeling methods. By managing the risks of torrential floods, which include integrated short-term and long-term measures and defence strategies, it could be provided the state roads' manager implements the protection of public roads and ensures the uninterrupted traffic flow in the torrent endangered places. A method of Flash Flood Potential Index (FFPI) was used to determine the terrain proneness to the torrential floods in the places related to the state road network. The method includes analysis of factors which define susceptibility to torrential floods in the certain area that are terrain slope, land use, soil type and vegetation density. Taking into account that physiographic parameters of a catchment have a large influence on time to peak and flood magnitude, we may assume that analysis of those parameters may be a valuable tool for the assessment of predisposition to torrent flood formation. The spatial analysis is performed using the remote sensing data on Digital Elevation Model (DEM), Bare Soil Index (BSI), CORINE and FAO Soil Database within GIS surrounding in order to analyse the relationship between torrential factors and spatial characteristics of the research area. The FFPI index is calculated using raster data, so that the research area is completely divided into cells, which are analyzed, reclassified and calculated using GIS technology. Based on the obtained FFPI values, the torrent endangered locations were classified into four classes, according to the susceptibility to torrential floods. The results show a total of 75 endangered locations, were classified as the medium endangerment class $(68 \%)$, followed by low endangerment (16\%), high endangerment $(10.66 \%)$ and very high endangerment $(5.33 \%)$ classes of road locations endangered by torrential floods. The spatial distribution of FFPI values provides a good starting point for flood risk management and the possibility for implementation of road prevention and protection measures.
\end{abstract}

Keywords: torrential floods, roads management, remote sensing, environmental modeling.

${ }^{1}$ Corresponding author: mladen.markovic@putevi-srbije.rs 


\section{Introduction}

The anthropogenic and technogenic impact of modern society on the environment has imposed the need to know and understand the natural conditions and processes that govern the Earth's surface. Construction activities often disturb the natural state of balance, which is manifested by the creation of various modern exogenous processes, which leads to damage or destruction of infrastructure (Đurić, 2016). In response to nature's anthropogenic pressures, natural disasters occur as a result of spatial interaction between extreme natural events and populations sensitive to such events (Degg, 1992). Torrential floods are one of the most common types of natural disasters in Serbia (Ristić et al., 2011; Dragićević et al., 2011, Stefanović et al., 2014). Torrential floods can be defined as floods that occur after rainfall of short duration and strong intensity (Marchi et al., 2010; Ristić and Malošević, 2011). The frequency and intensity of flash floods depend on the climate factors and physical-geographical characteristics of the terrain that make them a constant threat with consequences in the environmental, economic and social spheres. Torrential floods occur as a result of intense precipitation or sudden melting of snow, and are characterized by rapid formation torrent waves. The main characteristic of torrents is saturated with high concentrations sedimentation, short duration and great damage (Kostadinov, 2018). In Serbia, in the catastrophic floods of 2014, more than 1.6 million people were affected, a total of $945 \mathrm{~km}$ of roads and about 307 bridges were destroyed or damaged (Government of the Republic of Serbia, 2014). Increasingly frequent extreme rainfall of high intensity in a short period of time adversely affects bridges and structures in the trunk of the road, and the activation of torrents leads to a great threat to the road network. The genesis of high waters takes place in the upper part of the basin, while floods occur in river valleys, where road infrastructure is usually built. Spatial and temporal distribution of torrential floods endangers numerous road routes and leads to damage to roads, road bodies and traffic interruptions (Dragićević et al., 2019). Road sections in the zone of intersection with watercourses are especially exposed, where the functionality of road culverts is reduced or the incentive profile of bridge openings is reduced (Ristić et al., 2017). Flood risk management is a cycle that includes in its chain phases of prevention and protection, preparation, response and recovery in which short-term and long-term measures and strategies are integrated. All natural disasters, regardless of large essential differences, have common properties, namely-spatial specificity, temporal specificity, a certain frequency and consequences (Gavrilović, 2007). The occurrence, extent and duration of natural disasters, in this case torrential floods, can be predicted based on experience, statistics and modeling methods. The most commonly used method for determining terrain predisposition to torrential occurrence is the Flash Flood Potential Index (FFPI). The method was developed for basin monitoring that has shown good results in flood forecasting (Prăvălie and Costache, 2014; Minea et al., 2016; Lovrić et al., 2019). By using GIS software tools through a statistical approach, the established correlation between torrential factors and spatial characteristics of the basin can determine the risk of torrential floods (Tincu et al., 2018; Lee and Kim, 2019).

In this paper, for the study area a one part of Danube basin and Pek river basin, an analysis 
of the assessment of the threat to state roads from the occurrence of torrential floods using the FFPI method was performed. Based on the obtained results, the degree of endangerment of roads from torrential floods can be determined, which provide the possibility of prevention and taking measures for road protection. The contribution of this paper is to consider and solve the problem of torrential floods that can endanger roads both in the field of research and in other areas endangered by torrential floods.

\section{Materials and Methods}

\subsection{Study Area}

udy area is located in the eastern part of Serbia and consists of a part of the Danube basin that covers the area from places Veliko Gradište to Dobra and the Pek river basin, with an area of $1617.73 \mathrm{~km}^{2}$ (Fig. 1). According to Rakićević (1976), this area belongs to the Danube-Great Moravian climate region. From the demographic aspect, the municipal centers are the cities of Golubac, Veliko Gradište, Kučevo and Majdanpek. The Rhine-Danube corridor, whose total length through Serbia is $\mathbf{5 8 8}$ $\mathrm{km}$ from Bezdan to Timok, passes through the study area, is one of the nine European corridors of the TEN-T network and represents a significant component of traffic within the European single market. The area of study in terms of road infrastructure is a natural way to communicate with Romania and Bulgaria. The total length of state roads of I and II order located within the study area is $278 \mathrm{~km}$, of which according to the categorization of state roads: I B category 138 $\mathrm{km}$, II A category $86 \mathrm{~km}$ and II B category $54 \mathrm{~km}$.

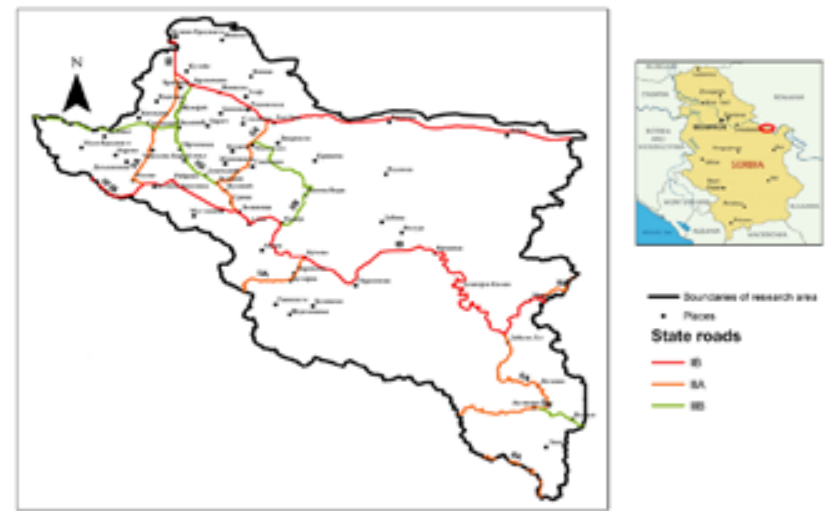

Fig. 1.

Study Area

Source: Authors

\subsection{Data Processing and Sources}

The Flash Flood Potential Index method was used to determine the predisposition of the research area to the occurrence of torrential floods. For the application of the FFPI method, digitized data are applied, which are converted into a raster data set, which are analyzed, reclassified and calculated using Geographic Information System (GIS) 
tools. The result is a quasi-static numerical index of flood potential determined for the research area in relation to the national road network. The FFPI index is determined on the basis of data on the slope and geometry of the basin, soil type, vegetation density and land use, which provide information on the possibility of torrents in a particular area (Smith, 2003). The FFPI is calculated according to the formula:

$$
F F P I=\frac{\mathrm{M}+\mathrm{S}+\mathrm{L}+\mathrm{V}}{4}
$$

$M$ - terrain slope index; $S$ - soil type index; $L$ - land use index; $\mathrm{V}$ - vegetation density index.

The terrain slope index was determined based on a digital elevation model (DEM), taken from the USGS database (USGS, 2019). For the purpose of determining the FFPI, for the slope of the terrain expressed in percent, the formula is applied:

$$
M=10^{n / 30}
$$

Where $\mathrm{n}$ is slope in \%. If $\mathrm{n}$ is greater or equal to $30 \%$, then $\mathrm{M}$ value is always 10 .

Soil type index is assigned coefficients from 1 to 10 , based on their characteristics that are important for the emergence and development of the torrent process. The land cover data used for the study area were taken from the Digital Soil Map of the World - Europe (FAO and Unesco, 2003). The basis for calculating the of land use index was the CORINE Land Cover class (CLC, 2018), which were assigned values from 1 to 10 , depending on the characteristics important for the emergence and development of the torrent process. The vegetation density index was obtained by analyzing multispectral images from the LANDSAT 8 satellite. The BSI index (Bare Soil Index) for the research area is calculated by the formula:

$B S I=\frac{(\mathrm{SWIR}+\mathrm{R})-(\mathrm{NIR}+\mathrm{B})}{(S W I R+R)+(N I R+B)}+1$

SWIR - value on the spectral channel from the shortwave infrared part of the spectrum; NIR - value on the spectral channel from the near infrared part of the spectrum;

$\mathrm{R}$ - value on the spectral channel $u$ from the red part of the spectrum;

$B$ - value on the spectral channel from the blue part of the electromagnetic radiation spectrum.

The vegetation density index ranges from 1 to 10 , the dependence between the BSI value and the vegetation density coefficient was determined and the formula was obtained:

$V=6.42 \cdot \ln (B S I)+10$

Based on the analysis of the obtained values of the FFPI index, the results were classified into four classes (very high, high, medium and low) in relation to the degree of susceptibility to torrents. The obtained results show the possibility of occurrence, ie predisposition of the terrain for the occurrence of torrents, under appropriate natural conditions.

\section{Results and Discussion}

\subsection{Factors of Torrential Floods}

\subsubsection{Hypsometric Characteristics of the Relief}

The hypsometric characteristics of the relief represent the basis of the analysis of the research area and provide information 
about the terrain we are analyzing (Fig. 2). Analysis of hypsometric characteristics of the study area found that $21.35 \%(324.8$ $\mathrm{km}^{2}$ ) of its territory is located at an altitude of less than $200 \mathrm{~m}$, while from 200 to $400 \mathrm{~m}$ is $25.45 \%\left(387.47 \mathrm{~km}^{2}\right), 200$ to $500 \mathrm{~m}$ above sea level is $10.33 \%\left(169.4 \mathrm{~km}^{2}\right)$, from 500 to $700 \mathrm{~m} \mathrm{39.2 \%}\left(732.85 \mathrm{~km}^{2}\right)$, from 700 to 960 $\mathrm{m}$ there is $3.8 \%$ of the basin relief $\left(6.21 \mathrm{~km}^{2}\right)$. Based on these data, it was calculated that the average altitude of the relief in the basin of the study area is $510.5 \mathrm{~m}$.

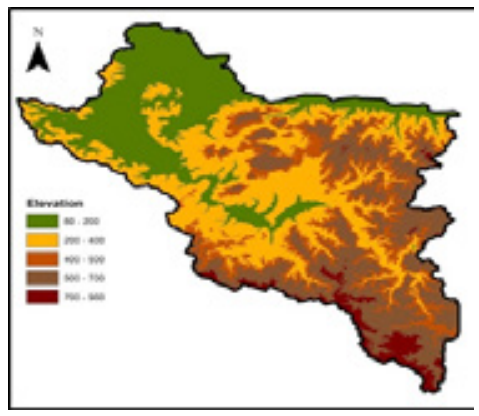

Fig. 2.

Hypsometric Map of the Research Area

Source: Authors

\subsubsection{Slope of the Relief}

The slope of the relief is one of the basic factors that define the intensity of erosive processes. If all other physical-geographical processes and characteristics of the relief are excluded, then it can be said that the intensity of erosion increases with the increase of the slope of the terrain. This is conditioned by the fact that with the increase of the slope of the terrain, the kinetic energy of the water that flows down the slope also increases. Analysis of the slope of the relief of the study area showed that slopes $>30^{\circ}$ occupy $72.92 \%$ of the total area (Fig. 3).

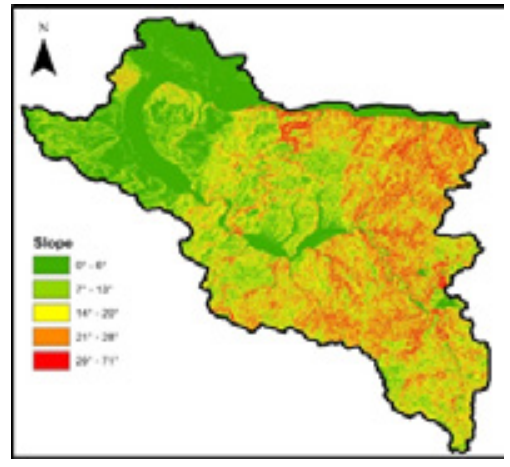

Fig. 3.

Map of the Slope of the Relief of the Research Area

Source: Authors 


\subsubsection{Soil Type}

Based on the available data, Fig. 4 shows the spatial distribution of the soil, eutric cambisol is represented in the research area. On steep slopes they are subject to erosion. Forest variants of these soils have good physical properties.

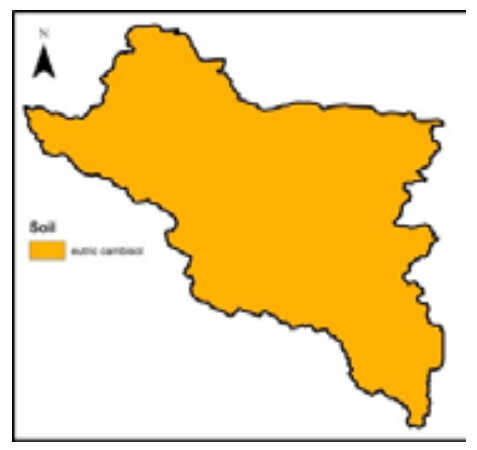

Fig. 4.

Pedological Map of the Research Area

Source: Authors

\subsubsection{Land Use}

Based on the CORINE land cover in 2018, the method of land use for the study area was determined (Fig. 5). CLC metadata, in addition to CLC databases, provides basic information about the content of the displayed areas for the study area. Metadata are prepared according to the standard structure prescribed by CLC TT (Nestorov and Protić, 2009), and CLC data sets are a valuable source of information for environmental monitoring, spatial planning, water management, etc. The analysis of the land cover database shows that out of the total number of classes that characterize the land cover of the study area, 19 CLC classes are represented. CLC class 311 (deciduous forests) dominates, covering $53 \%$ of the total area, followed by 243 (agricultural areas with a significant share of natural vegetation) with $11.2 \%, 242$ (agricultural parcel complex) with $7.34 \%$ of the total study area. 


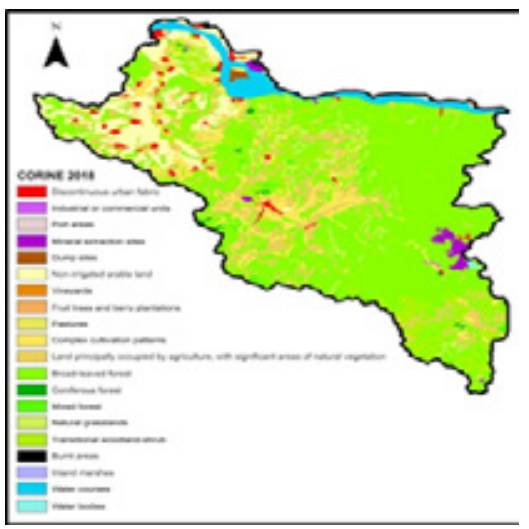

Fig. 5 .

Land use of the Research Area

Source: Authors

\subsubsection{Vegetation Density}

Based on the map of potential vegetation, the vegetation of the research area belongs to the association Quercetum frainetto-cerris - which is also the most common forest type in Serbia (Lakušić et al., 2005).

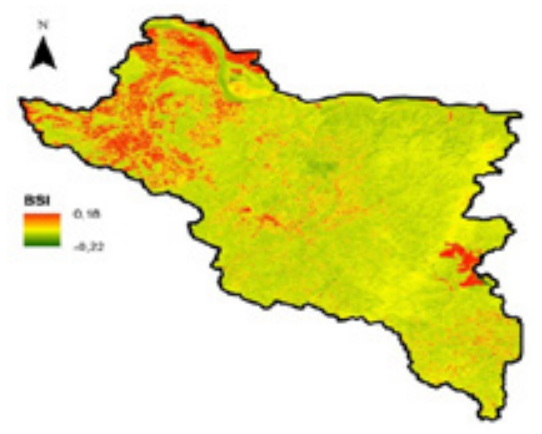

Fig. 6.

BSI Index (Bare Soil Index) of the Research Area

Source: Authors

After the classification of the obtained FFPI index, it was determined that the class of very high susceptibility is represented on 21.51 $\mathrm{km}^{2}$, ie $1.33 \%$ of the study area, and high on $243.47 \mathrm{~km}^{2}$, which represents $15.05 \%$ of its total area. The medium susceptibility class occupies $25.83 \%$, and the low $57.79 \%$ of the total area (Table 1). The dominant low susceptibility to torrents can be explained by the fact that terrains that are characterized by large slopes and are covered with dense vegetation, the degree of threat from torrents is significantly lower, in contrast to less sloping terrain, but unprotected vegetation. 


\section{Table 1}

Areas of Terrain Risk Classes by Torrential Floods according to the FFPI Method for the Study Area

\begin{tabular}{|c|c|c|}
\hline $\begin{array}{c}\text { FFPI Torrent } \\
\text { Susceptibility Classes }\end{array}$ & Area $\left[\mathbf{k m}^{2}\right]$ & Share in Total Area [\%] \\
\hline Very High & 21.51 & 1.33 \\
\hline High & 243.47 & 15.05 \\
\hline Medium & 417.86 & 25.83 \\
\hline Low & 934.89 & 57.79 \\
\hline Total & $\mathbf{1 6 1 7 . 7 3}$ & $\mathbf{1 0 0 . 0 0}$ \\
\hline
\end{tabular}

Source: Authors

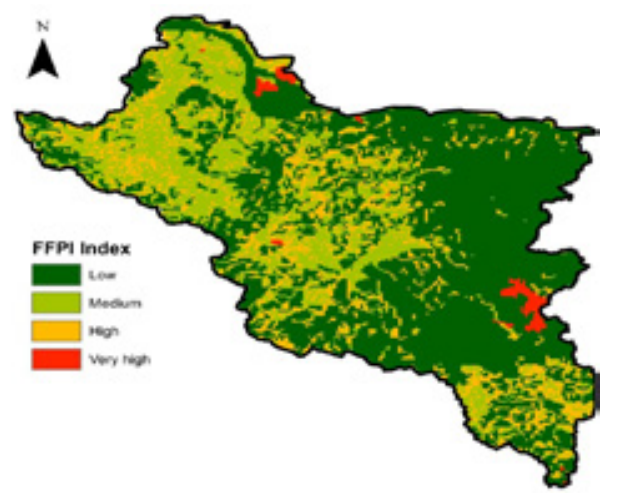

Fig. 7.

Predisposition of the Study Area to the Occurrence of Torrents by the FFPI Method

Source: Authors

\subsection{Endangerment of Roads to Torrential Floods}

The obtained FFPI index show the possibility of occurrence, ie predisposition of the terrain for the occurrence of torrents under appropriate natural conditions in relation to the maintained road network
(Fig. 8). The results of the analysis of road flood risk for the study area are shown in Table 2. Out of a total of 75 classified sites, the middle category of threat dominates with $68 \%$, followed by low risk (16\%), high risk (10.64\%) and very high (5.33\%) endangerment of roads locations from the occurrence of torrential floods.

Table 2

Number of Locations by Endangerment Category

\begin{tabular}{|c|c|}
\hline Endangerment Category & Number of Locations \\
\hline Low & 12 \\
\hline Medium & 51 \\
\hline High & 8 \\
\hline Very high & 4 \\
\hline
\end{tabular}

Source: Authors 
As the occurrence of torrents depends on a large number of factors, the spatial distribution of FFPI values on the state network provides an excellent starting point for flood risk management.

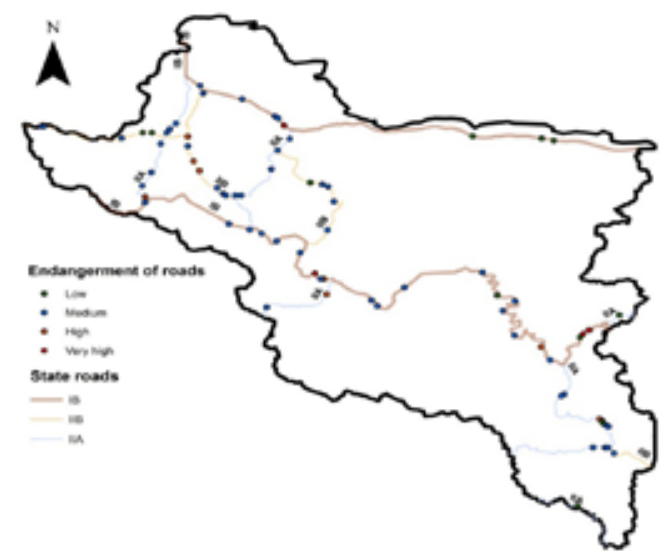

Fig. 8.

Locations on the Road Network with the Categorization of the Risk of Torrential Floods in the Research Area Source: Authors

Due to the frequent and more pronounced floods in Serbia, the passive attitude towards flood defenses must be changed to an active one, which includes defense and prevention measures. The only real defense against torrential floods is prevention, which consists in the integral regulation of torrential basins in order to reduce erosion processes to tolerant limits. Integral regulation of torrent basins of combinations of biotechnical, technical and administrative measures (Kostadinov and Borisavljević, 2012) will contribute to flood protection of existing and future roads. An effective preventive measure in preventing the occurrence of torrential floods on road sections is regular maintenance and cleaning of culverts from sediments and other materials, so that culvert profiles are at full capacity and cleaning of riverbeds in the zone of culverts and bridges.

\section{Conclusions}

Torrential floods are one of the most common natural disasters in Serbia, which can cause damage to the road infrastructure, lead to changes in the traffic regime and endanger the safety of traffic participants. The analysis of the FFPI index for the research area yielded the results of flood risk, which were classified into four classes depending on the degree of flood risk. By classifying the obtained FFPI index for the entire research area, it was determined that the class of very high susceptibility makes $1.33 \%$, and high $15.05 \%$ of the total area. The class of medium susceptibility occupies $25.83 \%$, and is dominated by low susceptibility to torrents (57.79\%) which can be explained by the coverage of the terrain with dense vegetation. The results 
of the predisposition of the research area for the occurrence of torrents in relation to the road network show that out of a total of 75 endangered locations, the medium endangerment category dominates at 51 locations, followed by low endangerment at 12 locations, high endangerment at 8 locations and very high endangerment at 4 road locations.

It can be concluded that the results of the application of FFPI methods provide information on conflicting locations of road and torrents that need special attention when planning traffic infrastructure and implementing flood defense measures.

\section{References}

CLC. 2018. Corine Land Cover. Available from Internet: $<w w w . l a n d . c o p e r n i c u s . e u>$.

Degg, M. 1992. Natural disasters: recent trends and future prospects, Geography 77(3): 198-209.

Dragićević, S.; Filipović, D.; Kostadinov, S.; Ristić, R.; Novković, I.; Țivković, N.; Djurdjić, S. 2011. Natural hazard assessment for land-use planning in Serbia, International Journal of Environmental Research 5(2): 371380.

Dragićević, S.; Kostadinov, S.; Novković, I.; Momirović, N.; Stefanović, T.; Radović, M.; Jeličić, M. 2019. Torrential floods as a risk factor for the road network in the Ibar basin. In Proceedings of Symposium: Planned and normative protection of space and environment, Palić Subotica, Serbia, 261-266.

Đurić, N. 2016. Modern construction of objects and contemporary landslides. In Proceedings of the IV international conference contemporary achievements in civil engineering, $22^{\text {nd }}$ April 2016, Subotica, Serbia, 469-477.
FAO and Unesco. 2003. Food and Agriculture Organization of the United Nations. Land and Water Development Division. Soil Map of the World - Europe, Version 3.6, completed January 2003, Rome, Italy. Available from Internet: <http://www.fao.org/soilsportal/soil-survey/soil-maps-and-databases/en/>.

Gavrilović, Lj. 2007. Natural disasters as a factor endangering the environment. In Proceedings of First Congress of Serbian Geographers, Belgrade.

Government of the Republic of Serbia. 2014. Floods in Serbia 2014 (Reconstruction Needs Assessment Report). Serbia Belgrade, 85-91.

Kostadinov, S. 2018. Study of endangerment of roads of I and II order from the occurrence of floods and torrents flows in the Ibar basin. Institute of Forestry \& Faculty of Geography, Belgrade. Available from Internet: <https:// bit.ly/2UOnT3w>.

Kostadinov, S.; Borisavljevic, A. 2012. Erosion protection and conservation of land and water in the world, Erosion 38(4): 1- 25.

Lakusić, D.; Blazević, J.; Ranđelović, B. 2005. Habitats of Serbia - a manual with descriptions and basic data, Institute of Botany and Botanical Garden "Jevremovac" Faculty of Biology, University of Belgrade.

Lee, B.J.; Kim, S. 2019. Gridded flash flood risk index coupling statistical approaches and TOPLATS land surface model for mountainous areas, Water 11(3): 504.

Lovrić, N.; Tošić, R.; Dragićević, S.; Novković, I. 2019. Assessment of torrential flood susceptibility: case study - ukrina river basin (B\&H), Bulletin of the Serbian geographical society 99(2): 1-16.

Marchi, L.; Borga, M.; Preciso, E.; Gaume, E. 2010. Characterisation of selected extreme flash floods in Europe and implications for flood risk management, Journal of Hydrology, 394(1-2): 118-133. 
Minea, G.; Iliescu, M; Dedu, F. 2016. Temporal rainfall properties at events scale in the Curvature Subcarpathians (Romania), Forum Geographic. 15 (2): 115-123.

Nestorov, I.; Protić, D. 2009. CORINE mapping of land cover in Serbia, Construction book, Belgrade.

Prăvălie, R.; Costache, R. 2014. The analysis of the susceptibility of the flash-floods' genesis in the area of the hydrographical basin of Bâsca Chiojdului river, Forum Geografic 13(1): 39-49.

Rakićević, T. 1976. Climatic characteristics of Eastern Serbia. In Proceedings of the Geographical Institute "Jovan Cvijić", Belgrade, 28: 41-67.

Ristić, R.; Radić, B.; Nikić, Z.; Trivan, G.; Vasiljević, N.; Dragićević, S.; Tivković, N.; Radosavljević, Z. 2011. Erosion control and protection from torrential floods in Serbia - spatial aspects, Spatium (25): 1-6.

Ristić, R.; Malošević, D. 2011. Hydrology of torrents floods. University of Belgrade, Faculty of Forestry. 221 p.

Ristić, R.; Milcanović, V.; Polovina, S.; Malusević I.; Radić B. 2017. Investigation of the impact of the network of forest roads and trains on the intensity of surface runoff and erosion processes for the needs of SP "Stara Planina" for FU "Pirot" - Pirot for 2017, University of Belgrade, Faculty of Forestry, Belgrade.
Smith, G. 2003. Flash Flood Potential: Determining the Hydrologic Response of FFMP Basins to Heavy Rain by Analyzing Their Physiographic Characteristics. Salt Lake City: NWS Colorado Basin River Forecast Center. Available from Internet: <https://www.cbrfc.noaa.gov/ papers/ffp_wpap.pdf $>$.

Stefanović, M.; Gavrilović, Z.; Bajčetić, R. 2014. Local Communities and Challenges of Torrential Floods, Organization for Security and Co-operation in Europe, Mission to Serbia, Belgrade. 9 p.

Tincu, R.; Lazar, G.; Lazar, I. 2018. Modified Flash Flood Potential Index in order to estimate areas with predisposition to water accumulation, Open Geosciences 10(1): 593-606.

USGS. 2019. U.S. Geological Survey. Available from Internet: <https://earthexplorer.usgs.gov/>. 